\title{
MATHEMATICAL MODELING AND OPTIMIZATION OF LOW- TEMPERATURE VACUUM DRYING FOR BANANA
}

\author{
Linh Thuy Khanh Do ${ }^{\circledR}$, Linh T. K. Vu ${ }^{1}$, Dao Thi Anh Phan ${ }^{1}$, Dzung N.T ${ }^{1 凶}$ \\ ${ }^{1}$ Department of Food Technology, Faculty of Chemical and Food Technology, HCMC University of Technology \\ and Education, No 01-Vo Van Ngan Street, Thu Duc City, Ho Chi Minh City, Viet Nam.

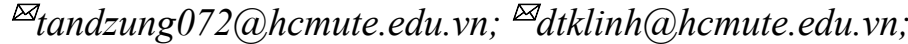 \\ https://doi.org/10.34302/crpjfst/2021.13.4.5 \\ Article history: \\ Received: \\ 17 March 2021 \\ Accepted: \\ 17 November 2021 \\ Keywords: \\ Modeling; \\ Vacuum drying; \\ Optimization; \\ Dried banana; \\ Low-temperature vacuum; \\ Drying.

\section{ABSTRACT} \\ Bananas are one of the most common energy yielding fruits, and also a \\ nutritional source for human health. In this study, low-temperature vacuum \\ drying was applied to preserve banana because this method offers a low \\ nutrient loss, a decrease in drying time leading to low energy cost, and the \\ low moisture content preventing products from microbial spoilage. Four \\ mathematical models were built, and a multi-objective optimization problem \\ was established for the drying process. The restricted area method with \\ $\mathrm{R}^{*}(\mathrm{Z})$ optimal combination criterion was used to optimize for the drying \\ mode of banana including temperature of $52.76^{\circ} \mathrm{C}$, pressure of $0.006 \mathrm{mmHg}$ \\ and drying time of 13.94 hours. Experimental results showed that the energy \\ consumption was $3.96 \mathrm{kWh} / \mathrm{kg}$, the residual water content was $3.64 \%$, the \\ vitamin C loss was $3.27 \%$ and the maximum rehydration capacity was 95.17 \\ $\%$, which convinced that dried bananas had achieved a minimum cost, the \\ best quality, and a long-term storage.
}

\section{Introduction}

Bananas (Musa spp., Musaceae) are one of the highly appreciated fruits over the world. Banana plants are usually found in tropical and subtropical regions because of their fastgrowing ability and good suitability with various types of fertilizer (Qamar et al., 2018). There are more than 300 banana varieties with planting area of approximately 5.2 million hectares (Qamar et al., 2018), (FAOSTAT, 2019). Most of varieties is widely distributed in IndoMalaysian, Asian, Caribbean, Latin American, African and Australia. As regards to the banana production yield, there were nearly 117 million tons of banana produced in 2019 (FAOSTAT, 2019). Ecuador, Costa Rica, and Philippines are countries that achieved the highest banana production and export yield whereas America, Belgium and Russia were the biggest banana importers 2017 (FAO, 2020).

Bananas are rich in biologically active compounds such as phenolics, vitamin $\mathrm{C}$, minerals, biogenic amines and phytosterols that beneficial for human health as well as effective in protecting the body against numerous oxidative stresses (Voora et al., 2020; Singh et al., 2016). Moreover, vitamin $\mathrm{C}$ is one of the most important substances against free radicals in human body. It also contributes to the growth of tissues, health of bones and teeth, the recovery of the wounds, the regeneration of collagen, the activation of hormones, the hydroxylation of proline and nitrosamine formation (Ranjha et al., 2020). Reducing the reactions relating to severe allergies, preventing human from being infected and positive moderating for the immune system are some of the advantages that vitamin $\mathrm{C}$ can also provide (Iqbal et al., 2004). $100 \mathrm{~g}$ fresh pulp of banana provides about $68 \mathrm{~g}$ of water, $121.8 \mathrm{~g}$ of carbohydrate, $30-60 \mathrm{mg}$ of phenolic compounds, $1.1 \mathrm{~g}$ of protein, $11.7 \mathrm{mg}$ of vitamin $\mathrm{C}, 1.0 \mathrm{mg}$ of sodium, $8.0 \mathrm{mg}$ of calcium, $385.0 \mathrm{mg}$ of potassium and other components (Qamar et al., 
2018). This nutrition fact could explain why the consumption of bananas gradually increases in several potential markets such as Europe and North America (WTO and International Trade Center, 2019).

However, bananas are prone to be perishable due to their high moisture content (Simal et al., 1997). There are about 1.6 million of bananas being spoiled and thrown away every day in developing countries. For instance, although the number of fresh bananas in Vietnam increased dramatically (approximately 1.4-1.9 million tons), banana exported yield only accounted for a minority in 2019 (FAO, 2020; (WTO and International Trade Center, 2019). Consequently, finding the best way to preserve this highly appreciated fruit as well as diversifying products made from banana are necessary.

There have been some methods for the longterm preservation and production of bananas including freezing, frying, and drying. Although freezing has been successfully employed to preserve food, the formation of ice crystals during freezing process could cause damage to the microstructure of food materials, leading to a decline in the preference of customers (Dzung N.T., 2016). Furthermore, the low temperature ranges used in freezing will cause a significant rise in energy cost (Dzung N.T., 2016). Another method applied for banana production is frying. This technique is beneficial since it forms the attractive appearance, adds flavor, and creates crispy texture for products. However, substantial odor enhancement via autoxidation, decomposition and fat hydrolysis may cause quality deterioration in fried products (Perkins E. I., 2007). A considerable increase of nutrition loss could occur inside products during frying (Mihaela et al., 2010).

On the other hand, drying is a popular method which has been applied for preserving fruits and vegetables since ancient times. Trends of drying are either to find an appropriate preservative technique for prolonging food shelf life or create ready-to-eat products retaining beneficial values for human health. In accordance with this advantage, drying is also a prevalent technique to preserve the original characteristics of bananas from structure, color, flavor to nutrition as well as increase the current level of acceptance of dried foods in the market (An H., et al., 2010). Utilizing high temperature over $70^{\circ} \mathrm{C}$ for water removal from foods will shorten the processing time and reduce moisture content for long storage. However, high temperature in drying could lead to some inherent disadvantages. The shrinkage on the surface of samples dried by conventional techniques was reported to be extremely high (Krokida et al., 1997). A greater shrinkage will result in a poor rehydration ratio and an unacceptable structure (Junlakan, 2014). Besides, the oxygen presence must be controlled in an extremely low range to have positive effects during drying and storage (Junlakan, 2014). If the oxygen level is high, the quality indicator of dried products as vitamin $\mathrm{C}$ will be degraded and rehydration capacity will be low. Therefore, low-temperature vacuum drying will offer a great potential for dehydration process. This method is recommended to create qualified dried products including fine structure (porosity and crispy), high nutritional properties (vitamin $\mathrm{C}$ retention) and good rehydration capacity. Furthermore, this new approach efficiently saves half of the energy cost as compared to sublimation drying (Bazyma and Kutovoy, 2005).

However, the application of lowtemperature vacuum drying to create highqualified dried banana chips have been untapped effectively. This matter occurs due to lack of equipment and experimental conditions to optimize the low-temperature vacuum drying process.

Therefore, the aim of this paper is modeling low-temperature vacuum drying process for banana by experimental designs. A multiobjective optimization problem describing for low-temperature vacuum drying is also established. The restricted area method with $\mathrm{R}^{*}(\mathrm{Z})$ optimal combination criterion is utilized to solve the problem and ascertain the Pareto tests. In other words, solving this multiobjective optimization problem is a way to optimize the low-temperature vacuum drying and figure out the optimal drying conditions for 
banana chips production. It is hypothesized that banana chips dried at these optimal parameters would meet all the quality standards such as minimal energy consumption, high nutritional values and low moisture content that could meet export requirements.

\section{Materials and methods}

\subsection{Materials}

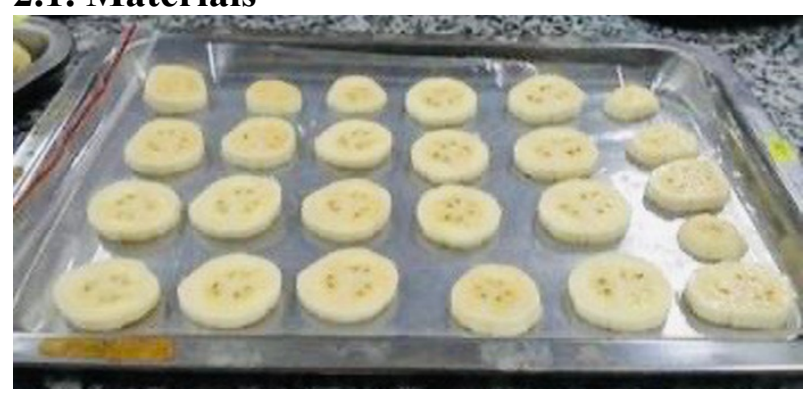

Figure 1. Fresh banana slices.

Fresh banana used for experiments was Pisang Awak variety (Musa acuminata x Musa balbisiana), collected from Southwestern area of Vietnam. This was chosen because of its superb quality, popularity, and high yields in Vietnam. The amount of carbohydrate in bananas has changed constantly upon ripening due to the transformation from starch to sugar by enzymatic breakdown mechanism (Hettiaratchi et al., 2011; Mohapatra et al., 2010). Limiting the changes of chemical compositions and controlling the homogeneity of fresh bananas play a vital role associated with choosing the appropriate material (Monteiro et al., 2015; Tribuzi and Laurindo, 2014; Zotarelli et al., 2012). Thus, bananas were initially examined the ripeness before being washed, peeled, sliced to $5 \mathrm{~mm}$ thickness, and uniformly arranged on a tray (Figure 1).

The thickness of $05 \mathrm{~mm}$ was chosen because thinner slices could be shrinkable and brittle after drying, whereas thicker slices would obstruct the migration of water from inside of material. This hindrance might lead to longer drying time and higher energy consumption.

\subsection{Methods}

\subsubsection{Drying equipment}

Dehydration process was conducted by using the low-temperature vacuum dryer prototype DSV-03, fabricated and assembled by Professor Nguyen Tan Dzung and his colleagues in 2018 (Duong T., et al., 2018). This machine is automatically controlled by coding and IoT and is placed at laboratory of Faculty of Chemical and Food Technology, Ho Chi Minh City University of Technology and Education, Vietnam (Figure 2).

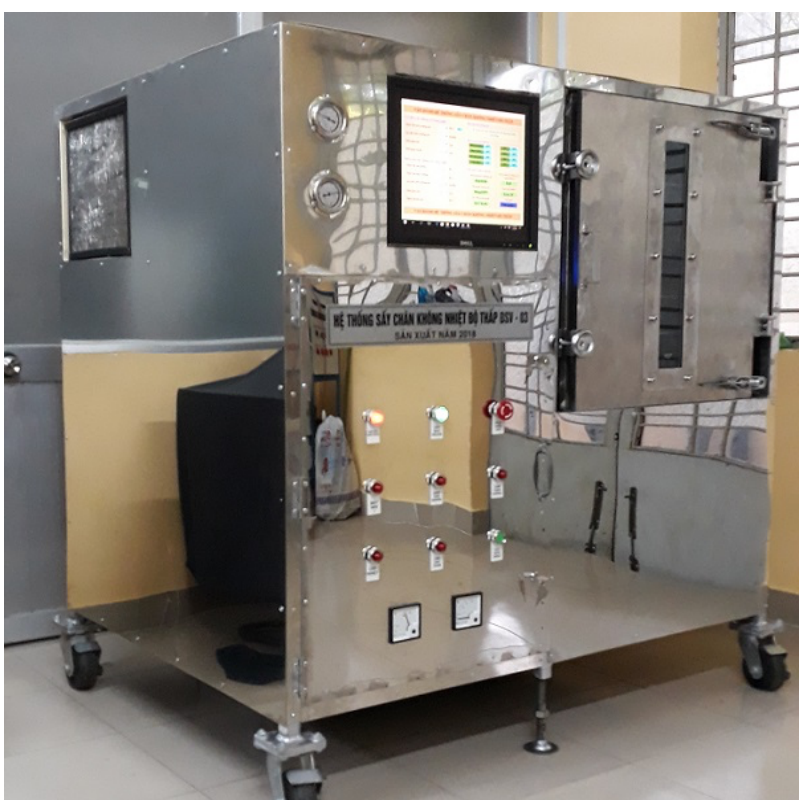

Figure 2. The low-temperature vacuum drying system DSV - 03 .

\subsubsection{Determination of the chemical compositions in fresh banana}

The following methods were used to determine some chemical compositions of Pisang Awak. Protein was measured by Kjeldahl method in FAO, Food \& Nutrition, 14/7, 1986. Carbohydrate and lipid were estimated by the standard of Ref. EC 152-2009 and Ref. EC 99606 , in turn. Vitamin $\mathrm{C}$ was calculated by direct titration with iodine (Suntornsuk et al., 2002). For determination of the banana ripeness, refractometric method was applied corresponding to standard of TCVN 7771:2007.

\subsubsection{Determination of the technological factors}

Factors affecting the low-temperature vacuum drying of banana included:

- Temperature $Z_{1}\left({ }^{\circ} \mathrm{C}\right)$

- Pressure $Z_{2}(\mathrm{mmHg})$

- Time $Z_{3}(\mathrm{~h})$ 
Temperature and pressure were recorded by sensors located inside the drying chamber, while drying time was estimated by a timer integrated in the computer of DSV-03 system.

\subsubsection{Determination of objective functions}

Although dried banana chips must achieve all the quality criteria together with a long-term storage, products' energy consumption should also be abridged. Therefore, the four objective functions including energy consumption, the residual water content, loss of vitamin $\mathrm{C}$ and the rehydration capacity of products were considered.

- The energy consumption $\left(\mathrm{y}_{1}, \mathrm{kWh} / \mathrm{kg}\right)$

The energy consumption $\left(\mathrm{y}_{1}, \mathrm{kWh} / \mathrm{kg}\right)$ for 1 $\mathrm{kg}$ of final product was determined by equation (1) (Dzung N.T., 2016), (Dzung N.T., 2012):

$$
y_{1}=\frac{P \cdot \tau}{G}(\mathrm{kWh} / \mathrm{kg})
$$

where: G (kg) - weight of final product; (s) - drying time; P (kW)-capacity shown on Watt meter.

- $\quad$ The residual water content $\left(\mathbf{y}_{2}, \%\right)$

The residual water content of final product was calculated by equation (2) (Dzung N.T., 2016), (Dzung N.T., 2012), (Dzung et al., 2016):

$$
y_{2}=100-\frac{G_{o}}{G_{e}}\left(100-W_{o}\right)
$$

where: $G_{o}(g)$ - weight of raw material; $G_{e}$ (g) - weight of final product; $\mathrm{W}_{\mathrm{o}}(\%)$ - the initial moisture content of sample.

- The loss of vitamin $\mathrm{C}\left(\mathrm{y}_{3}, \%\right)$

The loss of vitamin $\mathrm{C}$ in final product was estimated by the formula (Dzung N.T., 2016):

$$
y_{3}=\frac{m_{1}-m_{2}}{m_{1}} .100(\%)
$$

where: $\mathrm{m}_{1}$ and $\mathrm{m}_{2}(\mathrm{mg})-$ the vitamin $\mathrm{C}$ content before and after drying, respectively.

\section{- $\quad$ The rehydration capacity $\left(\mathbf{y}_{4}, \%\right)$}

Determining the rehydration capacity of final product was determined by the below expression (Dzung N.T., 2016):

$$
y_{4}=\frac{G_{1}-G_{e}}{G_{o}-G_{e}} 100(\%)
$$

where: $G_{0}(g)$ - weight of fresh banana slices used for the experiment; $\mathrm{G}_{1}(\mathrm{~g})$ - weight of dried slices which were soaked into the water at $25^{\circ} \mathrm{C}$ until the constant mass (the saturation of water content); $\mathrm{G}_{\mathrm{e}}(\mathrm{g})$ - weight of banana slices before soaking $(\mathrm{g})$.

2.2.5. Determination of microorganisms, mycotoxins, and heavy metals contents in dried products

The microbiological infection, the mycotoxins and heavy metal contents of dried products were measured by the following methods presented in Table 1, Table 2, and

\begin{tabular}{|c|c|c|c|}
\hline No. & Parameter & Unit & Method \\
\hline 1 & $\begin{array}{l}\text { Total aerobic } \\
\text { plate count }\end{array}$ & $\mathrm{cfu} / \mathrm{g}$ & $\begin{array}{l}\text { TCVN } \\
4884- \\
1: 2015 \\
\end{array}$ \\
\hline 2 & Coliforms & $\mathrm{cfu} / \mathrm{g}$ & $\begin{array}{l}\text { TCVN } \\
6848: 2007\end{array}$ \\
\hline 3 & $\begin{array}{l}\text { Escherichia } \\
\text { coli }\end{array}$ & $\mathrm{MPN} / \mathrm{g}$ & $\begin{array}{l}\text { TCVN } \\
6846: 2007\end{array}$ \\
\hline 4 & $\begin{array}{l}\text { Staphylococcus } \\
\text { aureus }\end{array}$ & $\mathrm{cfu} / \mathrm{g}$ & $\begin{array}{l}\text { TCVN } \\
4830- \\
1: 2005\end{array}$ \\
\hline 5 & $\begin{array}{l}\text { Clostridium } \\
\text { perfringens }\end{array}$ & $\mathrm{cfu} / \mathrm{g}$ & $\begin{array}{l}\text { TCVN } \\
4991: 2005\end{array}$ \\
\hline 6 & Bacillus cereus & $\mathrm{cfu} / \mathrm{g}$ & $\begin{array}{l}\text { TCVN } \\
4992: 2005\end{array}$ \\
\hline 7 & $\begin{array}{l}\text { Total spores of } \\
\text { yeast and mold }\end{array}$ & $\mathrm{cfu} / \mathrm{g}$ & $\begin{array}{l}\text { TCVN } \\
8275- \\
2: 2010\end{array}$ \\
\hline 8 & Salmonella & $\begin{array}{l}\text { per } \\
25 \mathrm{~g}\end{array}$ & $\begin{array}{l}\text { ISO } 6579- \\
1: 2017\end{array}$ \\
\hline
\end{tabular}
Table 3.

Table 1. Methods for the determination of microorganisms in dried bananas

Table 2. Method for the determination of mycotoxins content in dried bananas

\begin{tabular}{|c|l|l|l|}
\hline No. & \multicolumn{1}{|c|}{ Parameter } & Unit & \multicolumn{2}{|r|}{ Method } \\
\hline 1 & Aflatoxin $\mathrm{B}_{1}$ & $\mu \mathrm{g} / \mathrm{kg}$ & $\begin{array}{l}\text { Ref. } \mathrm{EN} \\
15662-2018\end{array}$ \\
\hline 2 & Aflatoxin & $\mu \mathrm{g} / \mathrm{kg}$ & $\begin{array}{l}\text { Ref. } \mathrm{EN} \\
15662-2018\end{array}$ \\
\hline
\end{tabular}


Table 3. Methods for the determination of heavy metals content in dried bananas

\begin{tabular}{|c|l|l|l|}
\hline No. & Parameters & Unit & Method \\
\hline 1 & Lead $(\mathrm{Pb})$ & $\mathrm{mg} / \mathrm{kg}$ & $\begin{array}{l}\text { Ref AOAC } \\
2015.01\end{array}$ \\
\hline 2 & Cadmium $(\mathrm{Cd})$ & $\mathrm{mg} / \mathrm{kg}$ & $\begin{array}{l}\text { Ref AOAC } \\
2015.01\end{array}$ \\
\hline
\end{tabular}

\subsubsection{Experimental planning method}

It is proposed that there was a simultaneous impact on the objective functions $\mathrm{y}_{1}, \mathrm{y}_{2}, \mathrm{y}_{3}, \mathrm{y}_{4}$ from the technological factors $Z_{1}, Z_{2}, Z_{3}$ (Figure 3).

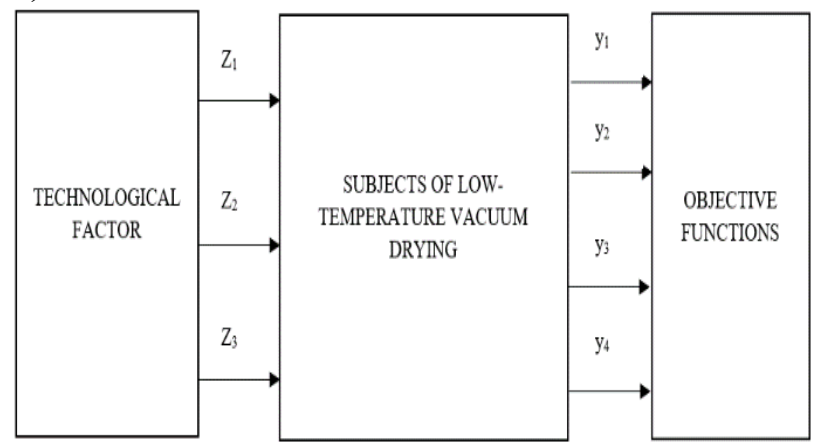

Figure 3. Diagram describing a relationship between the technological factors and the objective functions (Dzung et al., 2017)

An optimal experimental design was established to build a mathematical model assuring the accuracy, cost-saving, and a short experimental time. It was the quadratic orthogonal experimental plan, which $\mathrm{k}$ is the variables describing for the technological factors of the drying process $(\mathrm{k}=3)$.

Assuming that $\mathrm{x}_{1}, \mathrm{x}_{2}, \mathrm{x}_{3}$ were coded for variables $Z_{1}, Z_{2}, Z_{3}$. Thus, an experimental mathematical model was described as follow:

$$
\begin{gathered}
y_{j}=b_{o}+\sum_{j=1}^{k} b_{j} x_{j}+\sum_{\substack{j, i=1 \\
j \neq i}}^{k} b_{i j} x_{i} x_{j} \\
+\sum_{j=1}^{k} b_{j j}\left(x_{j}^{2}-\lambda\right)
\end{gathered}
$$

- Code variable was calculated by equation below:

$$
x_{j}=\frac{Z_{j}-Z_{j}^{o}}{\Delta Z_{j}}, \mathrm{j}=1 \div 3
$$

- Number of experiments:

$$
\mathrm{N}=2^{\mathrm{k}}+2 \mathrm{k}+\mathrm{n}_{0}=18
$$

- $\quad$ The star point (Dzung N.T., 2020):

$$
\alpha=\sqrt{\sqrt{N .2^{k-2}}-2^{k-1}}=1.414
$$

- Orthogonal matrix's criterion was:

$$
\lambda=\frac{1}{N}\left(2^{\mathrm{k}}+2 . \alpha^{2}\right)=0.667
$$

\subsubsection{Optimization method}

- The one - objective optimization problems

Every objective function $y_{j}=f_{j}(Z), j=1 \div 4$ depended on the technological elements including $\mathrm{Z}_{1}\left({ }^{\circ} \mathrm{C}\right)$ - drying temperature; $\mathrm{Z}_{2}$ $(\mathrm{mmHg})$ - pressure of drying environment; $\mathrm{Z}_{3}(\mathrm{~h})$ - drying time. Obviously, each objective function had a relationship with technological elements to form the one-objective optimization problem.

These factors formed the vector of technological elements or the $Z$ variable vector $Z=\left(Z_{1}, Z_{2}, Z_{3}\right)$. These variables varied in the identified domain $\Omega_{Z}$ and the function values $f_{j}(Z)$ formed the domain of the objective function $\Omega_{\mathrm{f}}$ (Dzung et al., 2017).

Therefore, to simplify without losing the generality, it was assumed that all objective functions could reach the minimum value. The one-objective optimization problem was hence stated as follow:

Determining the root of $Z^{j}=\left\{Z_{i}^{\text {jopt }}\right\}=\left(Z_{1}{ }^{\text {jopt }}\right.$, $\left.\mathrm{Z}_{2}{ }^{\text {jopt }}, \mathrm{Z}_{3}{ }^{\text {jopt }}\right) \in \Omega_{\mathrm{Z}}$ in order that:

$$
\left\{\begin{aligned}
y_{j \mathrm{~min}} & =f_{j}\left(Z_{i}^{j o p t}\right) \\
& =f_{j}\left(Z_{1}^{j o p t}, Z_{2}^{j o p t}, Z_{3}^{j o p t}\right) \\
& =\operatorname{Min}\left\{f_{j}\left(Z_{1}, Z_{2}, Z_{3}\right)\right\} \\
Z_{i}^{j o p t} & =\left(Z_{1}^{j o p t}, Z_{2}^{j o p t}, Z_{3}^{j o p t}\right) \in \Omega_{Z} \\
i=1 \div 3 & ; j=1 \div 4
\end{aligned}\right.
$$

- The multi - objective optimization problem

In fact, not only did the technological factors such as $Z_{1}\left({ }^{\circ} \mathrm{C}\right), Z_{2}(\mathrm{mmHg}), \mathrm{Z}_{3}$ (h) influence each objective function discretely, but they also coincided with these functions $y_{j}=f_{j}(Z), j=1 \div 4$ to fulfil all the economic and technological 
criteria. It was obvious that the multi-objective optimization problem had occurred in this research. Assuming the multi-objective optimization problem could be transformed into the problem to find the minimum value, the multi-objective optimization problem was stated:

Determining the root of $Z=Z^{\text {opt }}=\left(Z_{1}{ }^{\text {opt }}\right.$, $\left.\mathrm{Z}_{2}{ }^{\text {opt }}, \mathrm{Z}_{3}{ }^{\text {opt }}\right) \in \Omega \mathrm{z}$ so that:

$$
\left\{\begin{aligned}
y_{j \mathrm{~min}} & =f_{j}\left(Z_{i}^{o p t}\right) \\
& =f_{j}\left(Z_{1}^{o p t}, Z_{2}^{o p t}, Z_{3}^{o p t}\right) \\
& =\operatorname{Min}\left\{f_{j}\left(Z_{1}, Z_{2}, Z_{3}\right)\right\} \\
Z_{i}^{o p t}= & \left(Z_{1}^{o p t}, Z_{2}^{o p t}, Z_{3}^{o p t}\right) \in \Omega_{Z} \\
i=1 \div 3 & ; j=1 \div 4
\end{aligned}\right.
$$

Solving equation (10) to figure out the optimal root: $Z_{i}{ }^{\text {jopt }}=\left(Z_{1}{ }^{\text {jopt }}, Z_{2}{ }^{\text {jopt }}, Z_{3}{ }^{\text {jopt }}\right)$ in order that: $\mathrm{f}_{\text {jmin }}=\mathrm{f}\left(\mathrm{Z}_{\mathrm{i}}^{\text {jopt }}\right)=\operatorname{Minf}_{\mathrm{j}}(\mathrm{Z}), \forall \mathrm{i}=1 \div 3, \forall \mathrm{j}=$ $1 \div 4[9]$.

$$
\text { - } \quad \text { If } Z_{i}^{\text {jopt }}=Z_{i}^{\text {kopt }}(\forall j, k=1 \div 4 ; k \neq j) \text {, both }
$$

the utopian root and the utopian optimal plan exist. In addition, the test $\mathrm{Z}_{\mathrm{i}}{ }^{\mathrm{jopt}}=\left(\mathrm{Z}_{1}{ }^{\text {jopt }}, \mathrm{Z}_{2}{ }^{\text {jopt }}\right.$, $Z_{3}{ }^{\text {jopt }}$ ) was also the root of the multi-objective optimization problem (11).

- $\quad$ If $\mathrm{Z}_{\mathrm{i}}^{\mathrm{j} \text { opt }} \neq \mathrm{Z}_{\mathrm{i}}^{\mathrm{k} \text { opt }}(\forall \mathrm{j}, \mathrm{k}=1 \div 4 ; \mathrm{k} \neq \mathrm{j})$, the utopian root does not exist whereas the utopian point $f^{U T}=\left(f_{1 \min }, f_{2 \min }, f_{3 \min }, f_{4 \min }\right)$ can be normally determined. It has been reported that the multi-objective optimization problem (11) could be successfully solved by the restricted area method (Dzung et al., 2017).

Reality showed that most of the multiobjective optimization problems has its own objective functions $f_{j}(Z)$ subjected to the economic and technical conditions:

$$
f_{j}(Z)<\mathrm{C}_{j} ; \forall j=1 \div 4 ; \forall Z \in \Omega_{Z}
$$

Expression (12) formed the restricted area:

$$
C=\left\{f_{j}(Z) \geq \mathrm{C}_{j}\right\}
$$

The restricted area method suggested the $\mathrm{R}^{*}(\mathrm{Z})$ optimal combination criterion to solve the multi-objective objective optimization problem (11), defined as (Dzung et al., 2017):

$$
\begin{aligned}
R^{*}(Z) & =\left[\prod_{j=1}^{4} r_{j}(Z)\right]^{l / 4} \\
& =\sqrt[4]{r_{1}(Z) \cdot r_{2}(Z) \cdot r_{3}(Z) r_{4}(Z)}
\end{aligned}
$$

In which:

$$
\begin{aligned}
& r_{j}(Z)=\frac{C_{j}-f_{j}(Z)}{C_{j}-f_{j \min }} \text { khi } f_{j}(Z)<C_{J} \\
& r_{j}(Z)=0 \text { khi } f_{j}(Z) \geq C_{j}
\end{aligned}
$$

According to (15), if $f_{j}(Z) \rightarrow f_{j \text { min }}$ then $r_{j}(Z) \rightarrow r_{j \max }=1$. By choosing $\mathrm{R}^{*}(\mathrm{Z})$ as the objective function, the multi-objective optimization problem was restated as:

Finding the $\operatorname{root} Z^{R}=\left(Z_{1}^{R}, Z_{2}^{R}, Z_{3}^{R}\right) \in \Omega_{Z}$ in order that:

$$
\left\{\begin{array}{l}
R_{\max }^{*}=R^{*}\left(Z^{R}\right)=\operatorname{Max}\left\{R^{*}(Z)\right\} \\
=\operatorname{Max}\left\{\left[r_{1}(Z) \cdot r_{2}(Z) \cdot r_{3}(Z) \cdot r_{4}(Z)\right]^{\frac{1}{4}}\right\} \\
Z=\left(Z_{1}, Z_{2}, Z_{3}\right) \in \Omega_{Z}
\end{array}\right.
$$

The Pareto optimal root would be determined by solving (17). Hence, the Pareto effect was the optimal plan of the multiobjective optimization problem.

\subsubsection{Statistical analysis}

Microsoft Excel was utilized to calculate, solve, and build up the mathematical models describing for the low-temperature vacuum drying of bananas. In addition, MATLAB (2020) was also used to form the 3-D response surface plot simulating the objective functions from technological factors.

\section{Results and discussions}

\subsection{Chemical constituents of raw material}

Chemical constituents of fresh banana were summarized in Table 4. 
Table 4. Chemical constituents per $100 \mathrm{~g}$ of fresh banana pulp.

\begin{tabular}{|c|l|c|c|}
\hline No. & Nutrient & Unit & Value \\
\hline 1 & Moisture & $\%$ & 68.1 \\
\hline 2 & Protein & $\%$ & 0.87 \\
\hline 3 & Carbohydrate & $\%$ & 24.90 \\
\hline 4 & Lipid & $\mathrm{g}$ & $\mathrm{ND}$ \\
\hline 5 & Vitamin C & $\mathrm{mg}$ & 10.50 \\
\hline 6 & Brix & $\%$ & 22.9 \\
\hline
\end{tabular}

*ND: not detected

The amount of water in fresh bananas was approximately $68.1 \%$, which resembled to that of Hettiaratchi et al. (2011) who also found the moisture content of Pisang Awak banana was about 68.2\% (Hettiaratchi et al., 2011). Moreover, Dennis (1999) reported that under $20 \%$ of the residual water content of bananas is an ideal criterion to prevent foods from being spoiled by yeast, bacteria, molds, and enzymes (Dennis, 1999).

Regarding other chemical components of fresh bananas, they made up an insignificant ratio as compared to previous works (Qamar et al., 2018; Hettiaratchi et al., 2011; Mohapatra et al., 2010; Chandler, 2015). At limit of detection (LOD) value of $0.2 \mathrm{~g} / 100 \mathrm{~g}$, results also show that the lipid content was incredibly low in pulp. Nevertheless, the Brix value in this research was much higher than the other study (12-14\%) (Rex Harrill, 1998). Differences in the chemical compositions of banana pulp in this research could be due to the differences in the degree of ripeness, the climatic conditions of cultivated areas, and the quality of fertilizers along with types of cultivar (Hettiaratchi et al., 2011).

\subsection{Mathematical models describing the low- temperature vacuum drying of banana}

Table 5. Parameter level design

\begin{tabular}{|l|c|c|c|c|}
\hline \multicolumn{2}{|c|}{ Parameters } & $\begin{array}{c}\mathbf{Z}_{\mathbf{1}} \\
\left({ }^{\mathbf{0}} \mathbf{C}\right)\end{array}$ & $\begin{array}{c}\mathbf{Z}_{\mathbf{2}} \\
(\mathbf{m m H g})\end{array}$ & $\begin{array}{c}\mathbf{Z}_{\mathbf{3}} \\
(\mathbf{h})\end{array}$ \\
\hline$-\boldsymbol{\alpha}$ & -1.414 & 48.34 & 0.006 & 12.17 \\
\hline Low & -1 & 50 & 0.01 & 13 \\
\hline Central & 0 & 54 & 0.02 & 15 \\
\hline High & +1 & 58 & 0.03 & 17 \\
\hline$+\boldsymbol{\alpha}$ & 1.414 & 59.65 & 0.034 & 17.82 \\
\hline \multicolumn{2}{|l|}{ Deviation $\Delta \mathrm{Z}_{\mathrm{i}}$} & 4 & 0.01 & 2 \\
\hline
\end{tabular}

After conducting individual experiments for each technological factors $Z_{1}, Z_{2}, Z_{3}$ on the objective functions $y_{1}, y_{2}, y_{3}, y_{4}$, it could be presented that extrema domain of $\mathrm{y}_{\mathrm{j}}(\mathrm{j}=1 \div 4)$ varied in identified domain $Z_{i}(i=1 \div 3)$. The results were summarized in Table 5.

According to Table 6, the low-temperature vacuum drying experiments of bananas were proceeded, followed by the quadratic orthogonal matrix with $\mathrm{k}=3, \mathrm{n}_{0}=4$ to find out the objective functions $y_{j}(j=1 \div 4)$. The results were expressed in Table 6.

Table 6. Experimental matrix determining the objective functions.

\begin{tabular}{|c|c|c|c|c|c|c|c|c|}
\hline \multirow{2}{*}{\multicolumn{2}{|c|}{$\begin{array}{l}\begin{array}{c}\text { No. of } \\
\text { experiments }\end{array} \\
\mathrm{N}\end{array}$}} & \multicolumn{3}{|c|}{ Coded variables } & \multicolumn{4}{|c|}{ The objective functions } \\
\hline & & $\mathbf{x}_{1}$ & $\mathbf{x}_{2}$ & $\mathbf{X}_{3}$ & $\begin{array}{c}\mathbf{y}_{1} \\
(\mathbf{k W h} / \mathbf{k g})\end{array}$ & $\begin{array}{c}\mathbf{y}_{2} \\
(\%)\end{array}$ & $\begin{array}{c}\mathbf{y}_{3} \\
(\%)\end{array}$ & $\begin{array}{c}\mathbf{y}_{4} \\
(\%)\end{array}$ \\
\hline \multirow{8}{*}{$2^{\mathrm{k}}$} & 1 & 1 & 1 & 1 & 4.24 & 3.01 & 10.58 & 87.55 \\
\hline & 2 & -1 & 1 & 1 & 4.11 & 3.62 & 8.04 & 89.99 \\
\hline & 3 & 1 & -1 & 1 & 4.42 & 2.79 & 9.44 & 88.29 \\
\hline & 4 & -1 & -1 & 1 & 4.33 & 3.51 & 7.80 & 92.27 \\
\hline & 5 & 1 & 1 & -1 & 3.46 & 4.11 & 6.88 & 89.06 \\
\hline & 6 & -1 & 1 & -1 & 3.43 & 4.45 & 5.01 & 92.22 \\
\hline & 7 & 1 & -1 & -1 & 3.44 & 4.23 & 6.36 & 89.91 \\
\hline & 8 & -1 & -1 & -1 & 3.40 & 4.62 & 4.01 & 93.69 \\
\hline \multirow{3}{*}{$2 \mathrm{k}$} & 9 & 1.414 & 0 & 0 & 3.88 & 3.44 & 10.88 & 86.68 \\
\hline & 10 & -1.414 & 0 & 0 & 3.66 & 3.93 & 5.04 & 93.98 \\
\hline & 11 & 0 & 1.414 & 0 & 3.62 & 3.68 & 4.81 & 91.39 \\
\hline
\end{tabular}




\begin{tabular}{|c|c|c|c|c|c|c|c|c|}
\hline \multirow{5}{*}{} & 12 & 0 & -1.414 & 0 & 4.14 & 2.76 & 4.01 & 92.25 \\
\cline { 2 - 9 } & 13 & 0 & 0 & 1.414 & 4.97 & 2.57 & 10.23 & 87.39 \\
\cline { 2 - 9 } & 14 & 0 & 0 & -1.414 & 3.23 & 4.73 & 5.44 & 92.43 \\
\hline \multirow{4}{*}{$\mathrm{n}_{0}$} & 15 & 0 & 0 & 0 & 3.78 & 3.34 & 5.35 & 92.92 \\
\cline { 2 - 9 } & 16 & 0 & 0 & 0 & 3.81 & 3.18 & 5.41 & 92.88 \\
\cline { 2 - 9 } & 17 & 0 & 0 & 0 & 3.90 & 3.25 & 5.37 & 92.84 \\
\cline { 2 - 9 } & 18 & 0 & 0 & 0 & 3.81 & 3.17 & 5.79 & 92.26 \\
\hline
\end{tabular}

From Table 6, the experimental data was calculated using statistical theory and Microsoft Excel 2020 software before identifying the coefficients of regression equations $b_{j}, b_{j k}$ and $b_{\mathrm{jj}}$. Furthermore, the fitness of the regression equations with the experimental results was tested by Fisher test after the significance of coefficients was checked by Student test. The mathematical models of low-temperature vacuum drying for banana were presented below:

\section{- Energy consumption:}

$$
\begin{aligned}
& \mathrm{y}_{1}=3.847+0.05 \mathrm{x}_{1}-0.09 \mathrm{x}_{2}+0.486 \mathrm{x}_{3}- \\
& 0.067 \mathrm{x}_{1}^{2}+0.099 \mathrm{x}_{3}^{2}
\end{aligned}
$$

\section{- Residual water content:}

$$
\begin{aligned}
& \mathrm{y}_{2}=3.232-0.229 \mathrm{x}_{1}+0.112 \mathrm{x}_{2}-0.628 \mathrm{x}_{3}+ \\
& 0.268 \mathrm{x}_{1}^{2}+0.250 \mathrm{x}_{3}^{2}
\end{aligned}
$$

- Vitamin C loss:

$$
\begin{aligned}
& \mathrm{y}_{3}=5.505+1.388 \mathrm{x}_{1}+0.336 \mathrm{x}_{2}+1.698 \mathrm{x}_{3}+ \\
& 1.209 \mathrm{x}_{1}{ }^{2}-0.575 \mathrm{x}_{2}^{2}+1.146 \mathrm{x}_{3}^{2}
\end{aligned}
$$

- Rehydration capacity:

$$
\begin{aligned}
& \mathrm{y}_{4}=92.522-1.974 \mathrm{x}_{1}-0.546 \mathrm{x}_{2}-1.159 \mathrm{x}_{3}- \\
& 1.036 \mathrm{x}_{1}^{2}-1.247 \mathrm{x}_{3}{ }^{2}
\end{aligned}
$$

Currently, there have been very few studies for drying banana in low-temperature vacuum environment so that none of similar mathematical models could be used to make comparison. In the other hand, mathematical models (18), (19), (20) and (21) were compatible with experimental data so ensuring that these regression equations were precise to describe for the drying process. Thus, such equations could be utilized to set up technological parameters of dehydrated banana for commerce and export.
3.3. Optimization the banana lowtemperature vacuum drying process to establish the technological mode

\subsubsection{Solving the one - objective optimization problems}

The one-objective optimization problems were created after each object had been studied independently. These problems were found to achieve the minimum and maximum value including the energy consumption $\mathrm{y}_{1 \mathrm{~min}}=\mathrm{f}_{1}\left(\mathrm{x}_{1}\right.$, $\left.\mathrm{x}_{2}, \mathrm{x}_{3}\right)$; moisture content $\mathrm{y}_{2 \min }=\mathrm{f}_{2}\left(\mathrm{x}_{1}, \mathrm{x}_{2}, \mathrm{x}_{3}\right)$; vitamin $C$ loss $y_{3 \min }=f_{3}\left(x_{1}, x_{2}, x_{3}\right)$ and the rehydration capacity $\mathrm{y}_{4 \max }=\mathrm{f}_{4}\left(\mathrm{x}_{1}, \mathrm{x}_{2}, \mathrm{x}_{3}\right)$ with the identified domain $\Omega_{\mathrm{x}}=\left\{-1.414 \leq x_{1}, x_{2}\right.$, $\left.x_{3} \leq 1.414\right\}$. Consequently, the one-objective optimization problems were stated as follow:

Determining $\left(\mathrm{x}_{1}{ }^{\text {opt }}, \mathrm{x}_{2}{ }^{\text {opt }}, \mathrm{x}_{3}{ }^{\text {opt }}\right) \in \Omega_{\mathrm{x}}=$ $\left\{-1.414 \leq x_{1}, x_{2}, x_{3} \leq 1.414\right\}, \mathrm{j}=1 \div 4$ in order that:

$$
\left\{\begin{array}{c}
y_{1 \min }=f_{1}\left(x_{1}^{\text {opt }}, x_{2}^{1 \text { opt }}, x_{3}^{1 \text { opt }}\right) \\
=\operatorname{Min}\left\{f_{1}\left(x_{1}, x_{2}, x_{3}\right)\right\} \\
y_{2 \min }=f_{2}\left(x_{1}^{2 o p t}, x_{2}^{2 o p t}, x_{3}^{2 o p t}\right) \\
=\operatorname{Min}\left\{f_{2}\left(x_{1}, x_{2}, x_{3}\right)\right\} \\
y_{3 \min }=f_{3}\left(x_{1}^{3 o p t}, x_{2}^{3 o p t}, x_{3}^{3 o p t}\right) \\
=\operatorname{Min}\left\{f_{3}\left(x_{1}, x_{2}, x_{3}\right)\right\} \\
y_{4 \max }=f_{4}\left(x_{1}^{4 o p t}, x_{2}^{4 o p t}, x_{3}^{4 o p t}\right) \\
=\operatorname{Max}\left\{f_{4}\left(x_{1}, x_{2}, x_{3}\right)\right\}
\end{array}\right.
$$

Expression (22) was solved by using the Excel - Solver software. This resulted in the optimal roots of the one-objective optimization problems, summarized in Table 7. 
Table 7. Optimal roots of the one-objective optimization problems

\begin{tabular}{|c|c|c|c|c|}
\hline $\mathbf{j}$ & $\mathbf{x}_{\mathbf{1}}{ }^{\mathbf{j o p t}}$ & $\mathbf{x}_{\mathbf{2}}{ }^{\mathbf{j o p t}}$ & $\mathbf{x}^{\mathbf{j}}{ }^{\mathbf{j o t}}$ & $\mathbf{y j}_{\mathbf{j}}^{\mathbf{j o p t}}$ \\
\hline 1 & -1.414 & 1.414 & -1.414 & $\mathbf{3 . 0 3}$ \\
\hline 2 & 1.414 & -0.492 & 1.414 & $\mathbf{3 . 0 0}$ \\
\hline 3 & -0.452 & 0.000 & -1.309 & $\mathbf{4 . 8 7}$ \\
\hline 4 & -0.533 & -0.441 & -0.590 & $\mathbf{9 3 . 7 7}$ \\
\hline
\end{tabular}

As can be seen from Table 7, tests of the one-objective optimization problems from (18) to (21) satisfying all function values $\left(\mathrm{x}_{1}{ }^{\mathrm{jopt}}, \mathrm{x}_{2}{ }^{\mathrm{jopt}}\right.$, $\left.\mathrm{x}_{3}{ }^{\text {jopt }}\right) \neq\left(\mathrm{x}_{1}{ }^{\text {kopt }}, \mathrm{x}_{2}{ }^{\text {kopt }}, \mathrm{x}_{3}{ }^{\text {kopt }}\right) \forall \mathrm{j}, \mathrm{k}=1 \div 4, \mathrm{j} \neq \mathrm{k}$ could not be found. It was clear that cross tests of the one-objective optimization problems were inexistent. As a result, utopian roots and utopian optimal plans did not exist. Regardless of the inexistence of utopian roots, the utopian points were identified $\mathrm{y}^{\mathrm{UT}}=\left(\mathrm{y}_{1 \min }, \mathrm{y}_{2} \min , \mathrm{y}_{3} \min , \mathrm{y}_{4 \max }\right)=$ $(3.03 ; 3.00 ; 4.87 ; 93.77)$.

\subsubsection{Solving the multi-objective optimization problem}

Because all the one-objective optimization problems had none of cross tests fulfilling $\mathrm{y}_{1 \mathrm{~min}}$, $\mathrm{y}_{2 \min }, \mathrm{y}_{3} \min , \mathrm{y}_{4 \max }, \mathrm{t}$ the multi-objective optimization problem had to be taken into account to find the optimal Paréto test for optimal Paréto effect $\mathrm{y}_{\mathrm{p}}{ }^{\mathrm{R}}=\left(y_{1 p}^{R}, y_{2 p}^{R}, y_{3 p}^{R}\right.$, $\left.y_{4 p}^{R}\right)$ closest to the utopian point and the furthest from the restricted area. The main purpose of this paper was finding both maximum and minimum value. However, it is necessary to transform all the objective functions $\mathrm{y}_{1}, \mathrm{y}_{2}, \mathrm{y}_{3}$, $\mathrm{y}_{4}$ into one type of finding minimum value to simplify in the solution. The expressions were then rewritten as following:

$$
\left\{\begin{array}{l}
I_{1}(x)=y_{1}(x)=f_{1}\left(x_{1}, x_{2}, x_{3}\right) \\
I_{2}(x)=y_{2}(x)=f_{2}\left(x_{1}, x_{2}, x_{3}\right) \\
I_{3}(x)=y_{3}(x)=f_{3}\left(x_{1}, x_{2}, x_{3}\right) \\
I_{4}(x)=1 / y_{4}(x)=1 / f_{4}\left(x_{1}, x_{2}, x_{3}\right)
\end{array}\right.
$$

From (23), the multi-objective optimization problem was restated below:

Determining the optimal roots $\mathrm{x}^{\mathrm{opt}}=\left(\mathrm{x}_{1}{ }^{\mathrm{opt}}\right.$, $\left.\mathrm{x}_{2}{ }^{\mathrm{opt}}, \mathrm{x}_{3}{ }^{\mathrm{opt}}\right) \in \Omega_{\mathrm{x}}$ in order that:

$$
\left\{\begin{array}{c}
I_{j \min }(x)=f j\left(x_{1}^{o p t}, x_{2}^{o p t}, x_{3}^{o p t}\right) \\
=\operatorname{Min}\left\{f_{j}\left(x_{1}, x_{2}, x_{3}\right)\right\} \\
I_{j}(x)<C_{j} ; \forall j=1 \div 4 \\
-1.414 \leq x_{1}, x_{2}, x_{3} \leq 1.414
\end{array}\right.
$$

The objective functions $y_{j}(j=1 \div 4)$ must subject to the technological conditions such as: $\mathrm{I}_{1}=\mathrm{y}_{1} \leq \mathrm{C}_{1}$, with $\mathrm{C}_{1}=5 \mathrm{kWh} / \mathrm{kg} ; \mathrm{I}_{2}=\mathrm{y}_{2} \leq \mathrm{C}_{2}$, with $\mathrm{C}_{2}=6 \% ; \mathrm{I}_{3}=\mathrm{y}_{3} \leq \mathrm{C}_{3}$, with $\mathrm{C}_{3}=10 \%$; $\mathrm{y}_{4}$ $\geq \mathrm{C}^{\prime}{ }_{4}=90 \%$ so $\mathrm{I}_{4}=1 / \mathrm{y}_{4} \leq \mathrm{C}_{4}$, with $\mathrm{C}_{4}=1 / \mathrm{C}^{\prime}{ }_{4}=$ $1 / 90=0.011(1 / \%)$, albeit $y_{j}(j=1 \div 4)$ were affected by the technological factors $\mathrm{x}_{1}, \mathrm{x}_{2}, \mathrm{x}_{3}$. Therefore, the restricted area was investigated:

$$
\mathrm{C}=\left\{\mathrm{I}_{1}>\mathrm{C}_{1}=5 ; \mathrm{I}_{2}>\mathrm{C}_{2}=6 ; \mathrm{I}_{3}>\mathrm{C}_{3}=10 ; \mathrm{I}_{4}\right.
$$
$\left.>\mathrm{C}_{4}=0.011\right\}$

The $\mathrm{R}^{*}(\mathrm{x})$ optimal combination criterion was created by the restricted area method:

$$
\left\{\begin{array}{l}
R^{*}(x)=\left[\prod_{j=1}^{4} r_{j}\left(x_{1}, x_{2}, x_{3}\right)\right]^{l / 4} \\
\forall x=\left\{-1.414 \leq x_{1}, x_{2}, x_{3} \leq 1.414\right\} \in \Omega_{x}
\end{array}\right.
$$

In which

$$
\begin{aligned}
& \left\{\begin{array}{l}
r_{1}\left(x_{1}, x_{2}, x_{3}\right)=\frac{C_{1}-I_{1}(x)}{C_{1}-I_{1 \min }} k h i I_{1} \leq C_{1}=5 \\
r_{1}\left(x_{1}, x_{2}, x_{3}\right)=0 \mathrm{khi} I_{1}>C_{1}=5
\end{array}\right. \\
& \left\{\begin{array}{l}
r_{2}\left(x_{1}, x_{2}, x_{3}\right)=\frac{C_{2}-I_{2}(x)}{C_{2}-I_{2 \min }} k h i I_{2} \leq C_{2}=6 \\
r_{2}\left(x_{1}, x_{2}, x_{3}\right)=0 \mathrm{khi} I_{2}>C_{2}=6
\end{array}\right. \\
& \left\{\begin{array}{l}
r_{3}\left(x_{1}, x_{2}, x_{3}\right)=\frac{C_{3}-I_{3}(x)}{C_{3}-I_{3 \min }} k h i I_{3} \leq C_{3}=10 \\
r_{3}\left(x_{1}, x_{2}, x_{3}\right)=0 \quad k h i I_{3}>C_{3}=10
\end{array}\right. \\
& \left\{\begin{array}{l}
r_{4}\left(x_{1}, x_{2}, x_{3}\right)=\frac{C_{4}-I_{4}(x)}{C_{4}-I_{4 \min }} k h i I_{4} \leq C_{4}=0.011 \\
r_{4}\left(x_{1}, x_{2}, x_{3}\right)=0 \quad k h i I_{4}>C_{4}=0.011
\end{array}\right.
\end{aligned}
$$

According to the principle of building up the $R^{*}(x)$ optimal combination criterion (26), the multi-objective optimization problem was rewritten as follow: 
Determining the optimal Paréto roots $\mathrm{x}^{\mathrm{R}}=$ $\left(\mathrm{x}_{1}{ }^{\mathrm{R}}, \mathrm{x}_{2}{ }^{\mathrm{R}}, \mathrm{x}_{3}{ }^{\mathrm{R}}\right) \in \Omega_{\mathrm{x}}$ in order that:

$$
\left\{\begin{array}{c}
R_{\text {max }}^{*}=R^{*}\left(x^{R}\right)=R^{*}\left(x_{1}^{R}, x_{2}^{R}, x_{3}^{R}\right) \\
\quad=\operatorname{Max}\left\{\left[\prod_{j=1}^{4} r_{j}\left(x_{1}, x_{2}, x_{3}\right)\right]^{l / 4}\right\} \\
\forall x=\left\{-1.414 \leq x_{1}, x_{2}, x_{3} \leq 1.414\right\} \in \Omega_{x}
\end{array}\right.
$$

The maximum value $\mathrm{R}^{*}(\mathrm{x})$ in the optimal Paréto roots (28) was calculated by using the Excel-Solver software:

$$
\begin{aligned}
& \mathrm{R}_{\text {max }}^{*}=\operatorname{Max}\left\{\mathrm{R}^{*}\left(\mathrm{x}_{1}, \mathrm{x}_{2}, \mathrm{x}_{3}\right)\right\} \\
& \quad=R^{*}\left(x_{1}^{R}, x_{2}^{R}, x_{3}^{R}\right)=0.822 \\
& \text { Với }\left\{\begin{array}{l}
x_{1}^{R}=-0.310 \\
x_{2}^{R}=-1.414 \\
x_{3}^{R}=-0.529
\end{array}\right.
\end{aligned}
$$

Substituting these Paréto roots $\mathrm{x}_{1}{ }^{\mathrm{R}}, \mathrm{x}_{2}{ }^{\mathrm{R}}, \mathrm{x}_{3}{ }^{\mathrm{R}}$ into the regression equations (18), (19), (20) and (21), optimal Paréto effects were identified as the followings:

$$
\left\{\begin{array}{l}
y_{1}^{R}=3.72 \\
y_{2}^{R}=3.57 \\
y_{3}^{R}=2.99 \\
y_{4}^{R}=94.07
\end{array}\right.
$$

Converting the optimal Paréto roots $\mathrm{x}_{1}{ }^{\mathrm{R}}, \mathrm{x}_{2}{ }^{\mathrm{R}}$, $\mathrm{x}_{3}{ }^{\mathrm{R}}$ (29) into the uncoded variables, the optimal technological parameters were then obtained:

$$
\left\{\begin{array}{l}
Z_{1}^{o p t}=52.76^{\circ} \mathrm{C} \\
Z_{2}^{o p t}=0.006 \mathrm{mmHg} \\
Z_{3}^{o p t}=13.94 \mathrm{~h}
\end{array}\right.
$$

After solving the four-objective optimization problem, the optimal roots (31) could be found as $\mathrm{Z}_{1}{ }^{\mathrm{opt}}=52.76{ }^{\circ} \mathrm{C} ; \mathrm{Z}_{2}{ }^{\mathrm{opt}}=0.006$ $\mathrm{mmHg} ; Z_{3}{ }^{\text {opt }}=13.94$ hours. Applying this technological mode, we acquired the value of $y_{1}$ $=\mathrm{y}_{1}{ }^{\mathrm{R}}=3.72 \mathrm{kWh} / \mathrm{kg} ; \mathrm{y}_{2}=\mathrm{y}_{2}{ }^{\mathrm{R}}=3.57 \% ; \mathrm{y}_{3}=\mathrm{y}_{3}{ }^{\mathrm{R}}$ $=2.99 \% ; \mathrm{y}_{4}=\mathrm{y}_{4}^{\mathrm{R}}=94.07 \%$.

\subsection{Experiment to test the results of multi- objective optimization problem}

Carrying out the low-temperature vacuum drying process of banana at the optimal technological parameters, results were determined as the energy consumption per product weight of $\mathrm{y}_{1 \mathrm{E}}=3.96 \mathrm{kWh} / \mathrm{kg}$, residual water content of $\mathrm{y}_{2 \mathrm{E}}=3.64 \%$, vitamin $\mathrm{C}$ loss of $\mathrm{y}_{3 \mathrm{E}}=3.27 \%$ and rehydration capacity of $\mathrm{y}_{4 \mathrm{E}}=$ $95.17 \%$. It was obvious that the consequences $\left(\mathrm{y}_{1 \mathrm{E}}, \mathrm{y}_{2 \mathrm{E}}, \mathrm{y}_{3 \mathrm{E}}, \mathrm{y}_{4 \mathrm{E}}\right)$ were a little higher than the optimal Paréto tests but the increase was not dramatic. These findings conformed with the economic and technical standards to preserve the quality of banana, prolong shelf-life of products for commerce.

\subsection{Simulation of mathematical models on a 3-D response surface plot \\ MATLAB software 2020 was used to} simulate the objective functions $y_{j}(j=1 \div 4)$ from technological factors. Below are the results expressed in Figure 4, 5, 6, 7.

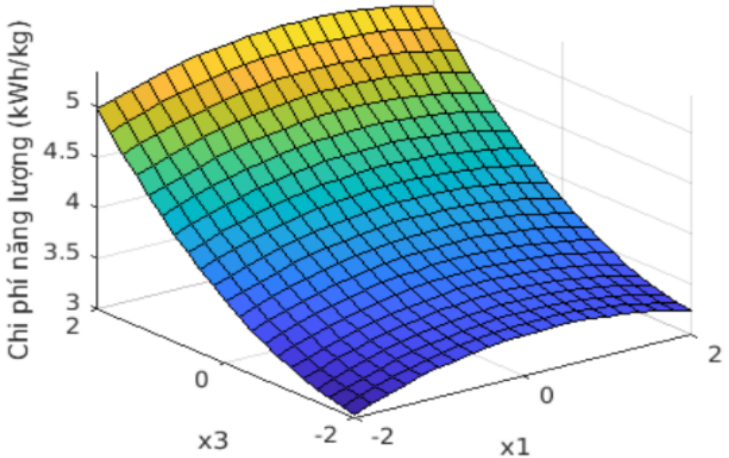

Figure 4. The energy consumption per weight product as $\mathrm{x}_{2}=-1.414$

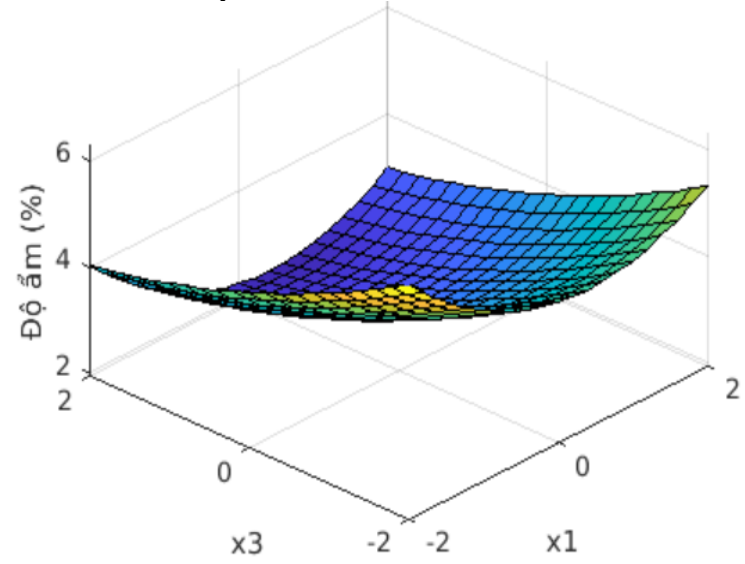

Figure 5. The residual moisture content as $\mathrm{x}_{2}$ $=-1.414$ 


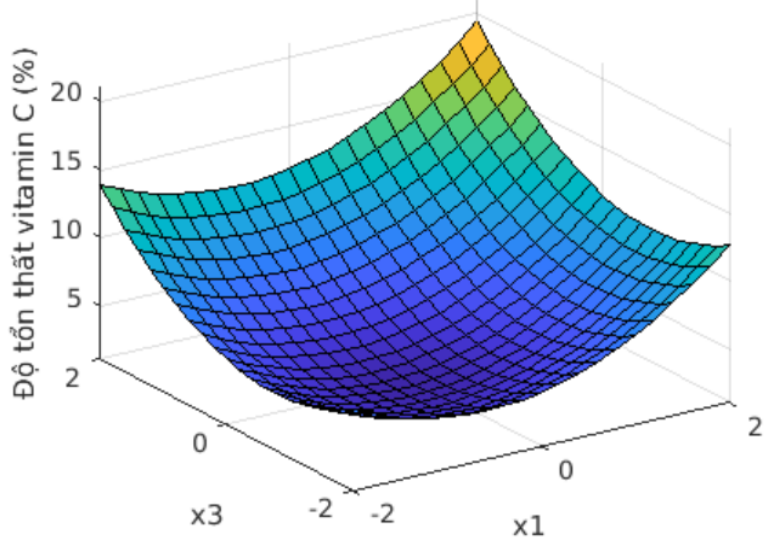

Figure 6. Vitamin C loss as $x_{2}=-1.414$

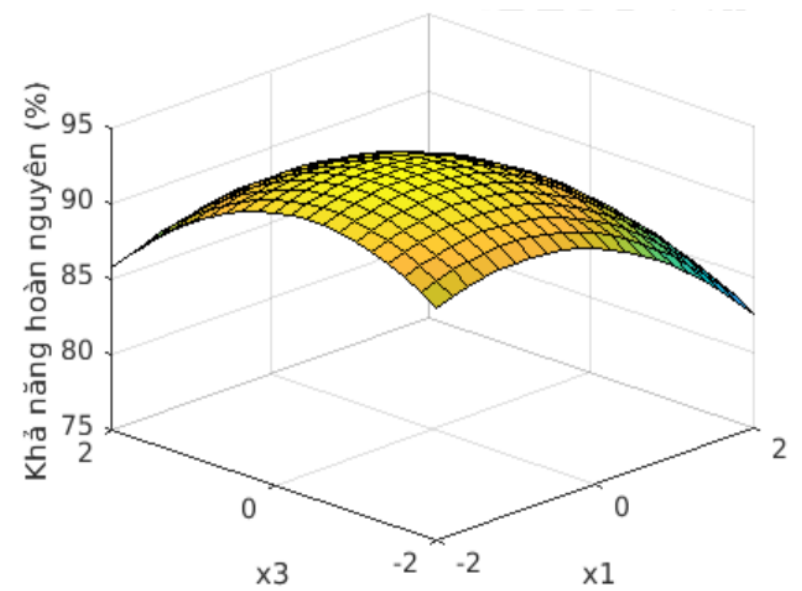

Figure 7. The rehydration capacity of products

$$
\text { as } \mathrm{x}_{2}=-1.414
$$

By applying the optimal conditions for vacuum drying process (31) including $Z_{1}=$ $52.76{ }^{\circ} \mathrm{C} ; Z_{2}=0.006 \mathrm{mmHg}$ and $Z_{3}=13.94$ hours, final products reached minimum energy consumption per weight of $3.96 \mathrm{kWh} / \mathrm{kg}$, made it become more economical as well as enhanced the probability for trade and export.

As regards to the energy consumption, remaining moisture content of dehydrated banana was $3.64 \%$. It is clear that less than $6 \%$ of the amount of water in foods offers a great opportunity for reducing water activity, which presents a key factor of dried product sustainability. Furthermore, food spoilage can be caused by microorganisms. Their growth depends mostly on the amount of available water. Water removal from foods positively influences on microbiological instability of dried products.
Vitamin C is easily degraded in foods, and the vitamin $\mathrm{C}$ degradation depends on many factors such as $\mathrm{pH}$, temperature, light, enzymatic process, and oxygen. Thus, vitamin $\mathrm{C}$ is considered as a quality indicator for foods (Moser and Bendich, 1991). In this paper, result of vitamin $\mathrm{C}$ loss proved that dried banana had achieved excellent quality, and this obtained data was better than previous works where vitamin C loss was ten times higher (Drouzas and Schubert 1996), (Jaya \& Das, 2003). Regarding the vacuum drying process, high deficiency of vitamin $\mathrm{C}$ in foods also caused by the relatively high level of pressure (over $10 \mathrm{mmHg}$ ) and temperature ranging from $60^{\circ} \mathrm{C}$ to $70^{\circ} \mathrm{C}$, so that most of quality attributes decreased substantially after drying (Drouzas and Schubert 1996), (Jaya \& Das, 2003). Besides, Junlakan (2014) and Sagar (2010) also reported when vacuum drying pressure had exceeded $10 \mathrm{mmHg}$, residual oxygen in chamber accelerated the oxidative reactions and lead to the intensification (Junlakan, 2014; Sagar and Kumar, 2010).

The rehydration capacity of $95.17 \%$ also met the technological requirements collating from Junlakan's research (Junlakan, 2014). The author suggested that rehydration ratio of dehydrated banana should be controlled over $90 \%$ to maintain good structure (Junlakan, 2014). Measurement of rehydration capacity could help researchers get insights about the denaturation of chemical components and nutritional characteristics of product (Junlakan, 2014). The higher the rehydration ratio is, the more porous structure obtains. Its shrinkage phenomenon is minimized, chemical compositions are less denatured as well as dried banana will maintain the qualified properties. However, if rehydration capacity is low, it means that texture of products is soft, the surface is shrinkable, the chemical constituents are denatured, and the quality of dried banana will not satisfy the requirements for trade.

Experiments also presented that drying banana at $70^{\circ} \mathrm{C}$ or above would cause shrinkage (Figure 8) and the rehydration capacity only reached $30 \%$. Drying banana under $55^{\circ} \mathrm{C}$ at optimal drying mode (31), products had less 
shrinkage, rehydration capacity was over $90 \%$ and its quality was better than conventional dried products (Figure 9).

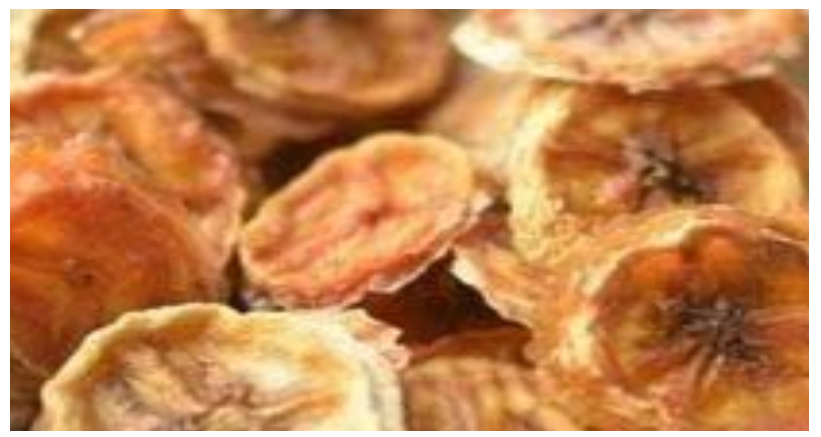

Figure 8. Infrared-dried banana in $70^{\circ} \mathrm{C}$

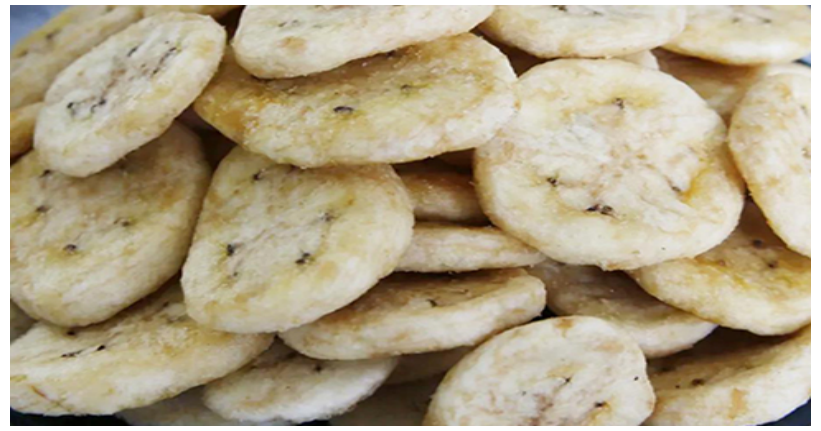

Figure 9. The low-temperature vacuum dried banana at optimal drying mode

\subsection{Evaluating nutritional quality of products}

Bananas dried at optimal technological conditions in the low-temperature vacuum environment were tested for the nutritional quality. The results were shown in Table 8.

Table 8. Chemical compositions of vacuum dried banana per $100 \mathrm{~g}$ dry weight

\begin{tabular}{|c|l|c|c|}
\hline No. & Components & Unit & Value \\
\hline 1 & Moisture & $\%$ & 3.64 \\
\hline 2 & Protein & $\%$ & 2.48 \\
\hline 3 & Carbohydrate & $\%$ & 72.12 \\
\hline 4 & Lipid & $\%$ & 0.39 \\
\hline 5 & Vitamin C & $\mathrm{mg} / 100 \mathrm{~g}$ & 31.84 \\
\hline
\end{tabular}

Once comparing with data in Table 4, the low-temperature vacuum dried banana accounted for a minority of nutritional loss. This statement could be demonstrated through the protein loss of $4.5 \%$, carbohydrate loss of $7 \%$ and vitamin $\mathrm{C}$ loss of $3.27 \%$. Thus, products had superb quality satisfying for market and export.

\subsection{Evaluating the microorganisms and heavy metal criteria}

The low-temperature vacuum dried banana was examined the microbiological infection, the limitation of mycotoxins and heavy metals. In case all the above criteria are fulfilled, the procedure of low-temperature vacuum drying of banana will be best suited for trade and export purposes. Results declaring for limitation of microbiological infection, mycotoxins and heavy metals were presented in Table 9, 10, and 11, respectively.

Table 9. Limit of microbiological infection

\begin{tabular}{|c|c|c|c|c|}
\hline \multicolumn{2}{|c|}{ Criteria } & Unit & Result & $\begin{array}{c}\text { Allowable } \\
\text { limit }\end{array}$ \\
\hline \multicolumn{2}{|c|}{$\begin{array}{l}\text { Total aerobic } \\
\text { plate count }\end{array}$} & $\mathrm{cfu} / \mathrm{g}$ & $4,0.10^{1}$ & $<10^{4}$ \\
\hline \multicolumn{2}{|c|}{ Coliforms } & $\mathrm{cfu} / \mathrm{g}$ & ND & $<10$ \\
\hline \multicolumn{2}{|c|}{$\begin{array}{l}\text { Escherichia } \\
\text { coli }\end{array}$} & MPN/g & ND & 0 \\
\hline \multicolumn{2}{|c|}{$\begin{array}{l}\text { Staphylococcus } \\
\text { aureus }\end{array}$} & $\mathrm{cfu} / \mathrm{g}$ & ND & $<20$ \\
\hline \multicolumn{2}{|c|}{$\begin{array}{l}\text { Clostridium } \\
\text { perfringens }\end{array}$} & $\mathrm{cfu} / \mathrm{g}$ & ND & $<10$ \\
\hline \multicolumn{2}{|c|}{ Bacillus cereus } & $\mathrm{cfu} / \mathrm{g}$ & ND & $<10^{3}$ \\
\hline \multicolumn{2}{|c|}{$\begin{array}{l}\text { Total spores of } \\
\text { yeast and mold }\end{array}$} & $\mathrm{cfu} / \mathrm{g}$ & ND & $10^{2}$ \\
\hline \multirow{2}{*}{\multicolumn{3}{|c|}{$\begin{array}{l}\text { Salmonella } \quad \text { per } 25 \mathrm{~g} \\
\text { *ND: not detected }\end{array}$}} & ND & $\mathrm{ND}$ in $25 \mathrm{~g}$ \\
\hline \multirow{2}{*}{\multicolumn{5}{|c|}{ Table 10. Limit of mycotoxins }} \\
\hline & & & & \\
\hline \multicolumn{2}{|c|}{\begin{tabular}{l|l} 
& \multicolumn{1}{c}{ Table 10. } \\
No. & Criteria
\end{tabular}} & Unit & Result & $\begin{array}{c}\text { Allowable } \\
\text { limit }\end{array}$ \\
\hline 1 & $\begin{array}{l}\text { Aflatoxin } \\
\mathrm{B}_{1}\end{array}$ & $\mu \mathrm{g} / \mathrm{kg}$ & ND & 2 \\
\hline 2 & $\begin{array}{l}\text { Aflatoxin } \\
\mathrm{B}_{1} \mathrm{~B}_{2} \mathrm{G}_{1} \mathrm{G}_{2}\end{array}$ & $\mu \mathrm{g} / \mathrm{kg}$ & ND & 4 \\
\hline
\end{tabular}

*ND: not detected

Table 11. Limit of heavy metals

\begin{tabular}{|c|l|c|c|c|}
\hline No. & Criteria & Unit & Result & $\begin{array}{c}\text { Allowable } \\
\text { limit }\end{array}$ \\
\hline 1 & Lead $(\mathrm{Pb})$ & $\mathrm{mg} / \mathrm{kg}$ & $\mathrm{ND}$ & 0,1 \\
\hline 2 & $\begin{array}{l}\text { Cadmium } \\
(\mathrm{Cd})\end{array}$ & $\mathrm{mg} / \mathrm{kg}$ & $\mathrm{ND}$ & 0,05 \\
\hline
\end{tabular}

*ND: not detected

Results summarized in Table 9, 10, 11 presented that all criteria complied with the allowance limits. These limits were specified in "Guidelines for Assessing the Microbiological 
Safety of Ready-to-Eat Foods Placed on the Market" edited by Health Protection Agency, London (Health Protection Agency, 2009); Codex standards (Codex, 1997; Codex, 2003); Commission Regulation (EC) No. 2073/2005 and 1881/2006 (European Commission, 2005; European Commission, 2006). Therefore, lowtemperature vacuum dehydrated banana chips in this study fulfilled all the prerequisites in terms of hygiene, food safety and export.

\subsection{Production of low-temperature vacuum dried banana}

After the technological mode had been determined, the entire procedure for banana chip production by low - temperature vacuum drying was standardized and presented in Figure 10.

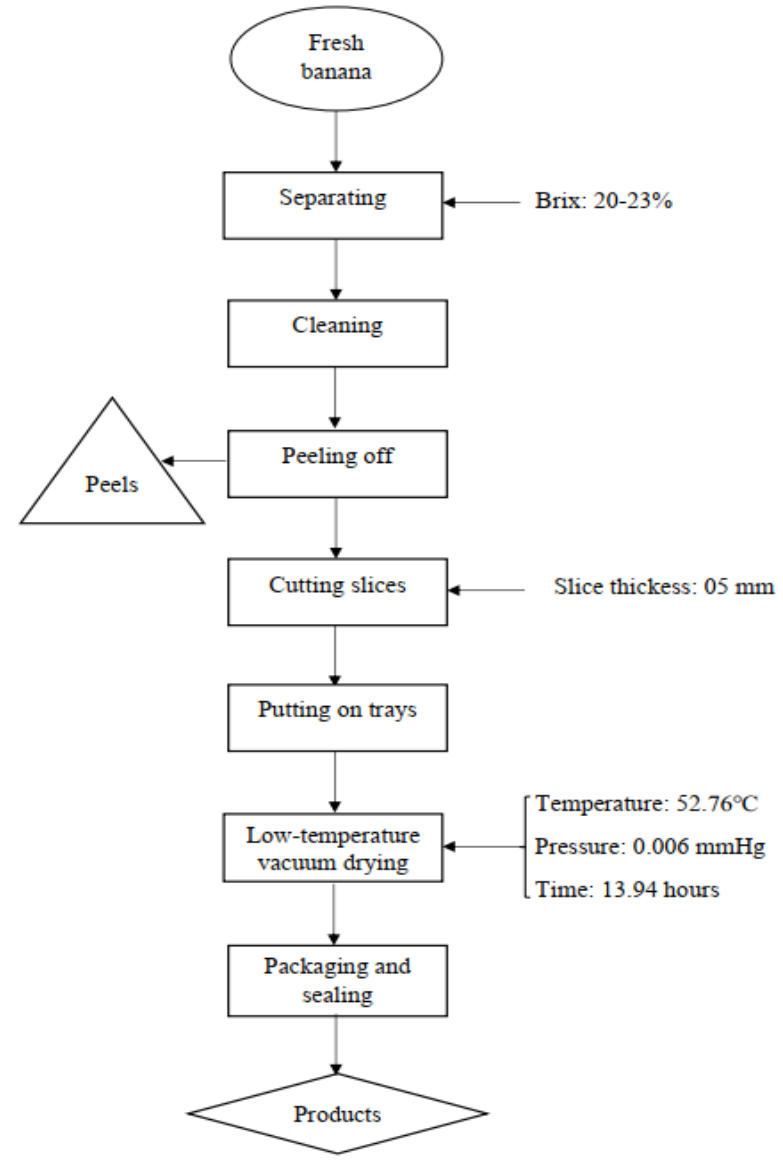

Figure 10. Flowchart of producing lowtemperature vacuum dried banana

This procedure commenced when fresh banana was separated and removed the fingers spoiled by transportation. Following that, the ripeness was tested by refractometer (Brix $\approx 20 \div$ $23 \%$ ) before fresh bananas were cleaned to remove impurities on fruit skin and peeled off for chip production. Next, banana was cut into slices with $05 \mathrm{~mm}$ thickness and put on tray. After placing all trays in the drying chamber, closed the door tightly and started the drying process with parameters: $52.76^{\circ} \mathrm{C}, 0.006 \mathrm{~mm} \mathrm{Hg}$ and 13.94 hours. Finished products were put into PE bags and sealed (Figure 11).

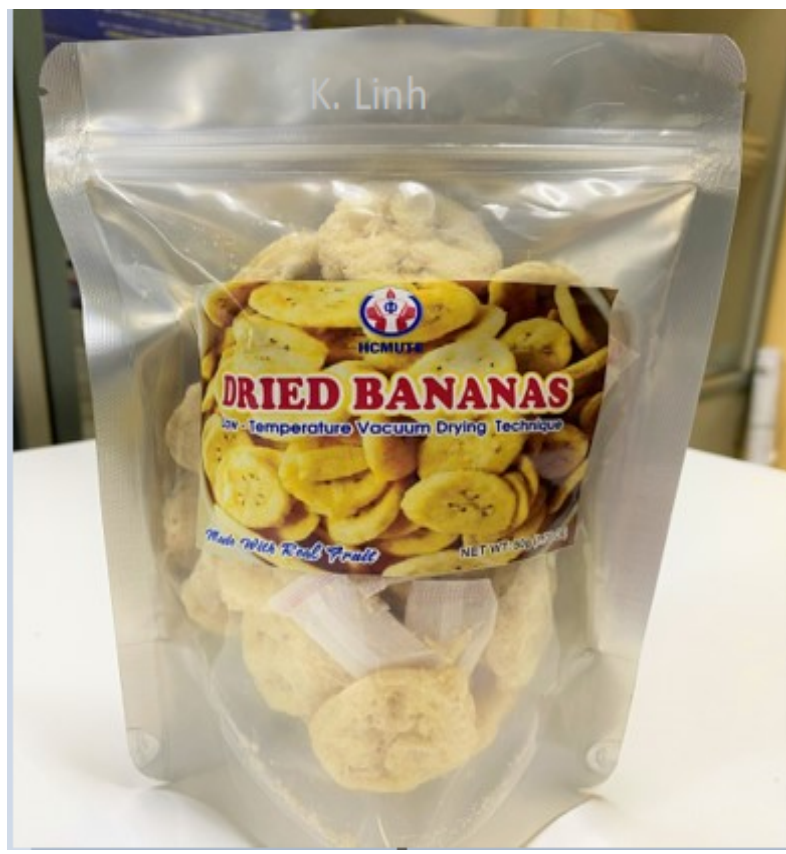

Figure 11. The low-temperature vacuum dried banana at optimal technological mode

\section{Conclusions}

To form the mathematical models and solve it to find the technological mode for vacuum drying of bananas, this study had resolved some crucial initial targets:

- Determining chemical compositions of fresh banana to ensure that the starting material is the same and the banana quality is homogeneous before drying.

- Modeling the low-temperature vacuum drying process of banana by experimental planning method, shown by expressions (18), (19), (20) and (21). Therefore, these mathematical models can be easily used to establish the technological conditions for vacuum drying of banana slices.

- Optimizing the low-temperature vacuum drying process by building and solving the oneobjective optimization problems and the multiobjective optimization problem via the restricted 
area method. This resulted in the determination of optimal parameters including the temperature of drying $52.76{ }^{\circ} \mathrm{C}$, vacuum pressure 0.006 $\mathrm{mmHg}$ and drying time of 13.94 hours. Final products positively obtained the energy consumption per $1 \mathrm{~kg}$ of final product was 3.96 $\mathrm{kWh} / \mathrm{kg}$, the residual moisture content was $3.64 \%$, vitamin C loss was $3.27 \%$ and rehydration capacity was $95.17 \%$. These consequences completely satisfied all the conditions regarding economy and technique of vacuum drying.

- Establishing the whole process of drying banana in low-temperature vacuum environment for trade and export (Figure 10).

\section{References}

An H., Nghiêm N., Anh H., Thinh L., Yen N.,. 2010. Assessing initial realities and proposing some economic methods to produce Gross Michel banana in Vietnam for export. Vietnamese Journal of Agricultural and Rural Development, 205209.

Bazyma, L.A., Kutovoy, V.A. (2005). Vacuum drying and hybrid technologies. Stewart Postharvest Review, 4(7), 1-5.

Codex Alimentarius Commission (2003). CX/NEA 03/16: Working paper on elaboration of a regional standard for microbiological levels in foods, 1-20.

Codex Alimentarius Commission (1997). CXG 21 - 1997: Principles and Guidelines for the Establishment and Application of Microbiological Criteria Related to Foods, 1-6.

Chandler, S. (2015). The nutritional value of bananas. In Bananas and plantains. (pp. 468480), Springer.

Drouzas, A. E., Schubert, H. (1996). Microwave application in vacuum drying of fruits. Journal of food engineering, 28, 203-209.

Dennis, S. (1999). Improving Solar Food Dryers. Home Power Magazine, 69, 24-34.

Dzung, N.T. (2016). Process and Equipment in Food Technology: Freeze drying technique. HCM City Publishing House of National University.
Dzung, N.T., Vinh, Q. N., Tuan, T. C. (2017). Modeling and optimization in Chemical and Food Technology. HCM City Publishing House of National University.

Dzung, N.T. (2012). Optimization The Freeze Drying Process of Penaeus Monodon to Determine the Technological Mode. International Journal of Chemical Engineering and Applications, 3(2), 187194

Dzung, N.T., Phương, V.D. (2016). The Multiobjective Optimization by the Restricted Area Method to Determine the Technological Mode of Cold Drying Process of Carrot Product. Research Journal of Applied Sciences, Engineering and Technology, 13(1), 64-74.

Dzung, N.T., Duyen, D.M.N., Linh, T.K.Do. (2020). Multi-objective optimization to determine the cold drying mode of gac (Momordica cochinchinensis spreng). Carpathian Journal of Food Science \& Technology, 12(3), 23-34.

Duong, T., Hao V., Linh, T. K. Do, Nhat H., Nhu P., Vy V., Cuong L., Phong L.; Dzung N.T. (2018). Study and manufacture of the low temperature vacuum drying system in pillot scale. Journal of Technical Education Science, 1-6.

European Commission. (2006). Commission Regulation (EC) No 1881/2006. Official Journal of the European Union, 5-24.

European Commission. (2005). Commission Regulation (EC) No 2073/2005. Official Journal of the European Union, 1-26.

FAOSTAT. (2019). Food and And Agriculture Organization of the United Nations. Accessed 9/2/2021. http://faostat.fao.org/.

FAO. (2020). Banana Market Review: Preliminary Results 2019. Rome.

Health Protection Agency. (2009). Guidelines for Assessing the Microbiological Safety of Ready-to-Eat Foods. Health Protection Agency.

Hettiaratchi, U. P. K., Ekanayake, S., Welihinda J. (2011). Chemical compositions and glycemic responses to banana varieties. International Journal of Food Sciences, 62 (4), 307-309. 
Iqbal, K., Khan A., Khattak, M. M. (2004). Biological Significance of Ascorbic Acid (Vitamin C) in Human Health - A Review. Pakistan Journal of Nutrition, 3(1), 5-13.

Jaya, S., Das, H. (2003). A vacuum drying model for mango pulp. Drying Technology, 21(7), 1215-1234.

Junlakan, W. (2014). Effect of Drying Kinetics on the Quality of Vacuum - Dried Banana, Pineapple and Apple Slices. Prince of Songkla University, Thailand, 1-224.

Krokida, M. K., Maroulis, Z. B. (1997). Effect of drying method on shrinkage and porosity. Drying Technology: An International Journal, 15(10), 2441-2358.

Mohapatra, D., Sabyasachi, M., Namrata S. (2010). Banana and its by-product utilisation: an overview. Journal of Scientific \& Industrial Research, 69, 323329.

Mihaela, G., Mira, T., George, B., Petru, N., Vasilica, S. (2010). Nutritional and health aspects related to frying. Romanian Biotechnological Letters, 15(6), 5675-5682.

Monteiro, R. L., Carciofi, B.A.M., Marsaioli, Jr. A., Laurindo, J. B. (2015). How to make a microwave vacuum dryer with turntable. Journal of Food Engineering, 166, 276-284.

Moser, U., Bendich, A. (1991). Vitamin C. In Handbook of Vitamins. (pp. 195-224), Marcel Dekker.

Perkins, E. I. (2007). Volatile odor and flavor components formed in deep frying. In Deep Frying: Chemistry, Nutrition and Practical Application. AOCS Press.

Qamar, S., Shaikh, A. (2018). Therapeutic potentials and compositional changes of valuable compounds from banana- A review. Trends in Food Science \& Technology, 79, 1-9.

Ranjha, M. M. A. N., Shafeeqa, I., Muhammad, N.; Shahid, M. (2020). A Comprehensive Review on Nutritional Value, Medicinal Uses, and Processing of Banana. Food Reviews International, 1-28.

Rex Harrill. (1998). Using a refractometer to test the quality of fruits and vegetables. Pineknoll Publishing.
Singh, B., Jatinder, S., Amritpal, K., Narpinder, S. (2016). Bioactive compounds in banana and their associated health benefits - a review. Food Chemistry, 206, 1-11.

Sagar, V. R., Suresh, Kumar, P. (2010). Recent advances in drying and dehydration of fruits and vegetables: a review. Journal of Food Science and Technology, 47(1), 15-26.

Simal, S., Deya, E., Frau, M., Rossello C. (1997). Simple modeling of air-drying curves of fresh and osmotically predehydrated apple cubes. Journal of Food Engineering, 33, 139-150.

Tribuzi, G., Laurindo, J. B. (2014). How to adapt a lab-scale freeze dryer for assessing dehydrating curves at different heating conditions. Drying Technology, 32, 11191124.

Voora, V., Larrea, C., Bermudez, S. (2020). Global Market Report: Bananas. Canada: the International Institute for Sustainable Development.

WTO., International Trade Center. (2019). Study on Vietnamese Fruits overcome barriers to access EU market, takes advantage of oppotunities brought under the EVFTA. Vietnam Chamber of Commerce and Industry.

Zotarelli, M. F., Porciuncula, B. D. A., Laurindo, J. B. (2012). A convective multi flash drying process for producing dehydrated crispy fruits. Journal of Food Engineering, 08, 523-531.

\section{Acknowledgments}

The authors would like to thank Head of Lab Food Engineering and Technology, Department of Food Technology, Faculty of Chemical and Food Technology, HCMC University of Technology and Education, Vietnam, for his assistance with the experiments. 